\title{
Voluntary and Community Sector Policy under the Coalition Government
}

\author{
Chris Dayson and Peter Wells* \\ CRESR, Sheffield Hallam University
}

\begin{abstract}
This paper reviews changes to the policy environment for the voluntary and community sector since the formation of Coalition Government in the United Kingdom in May 2010. It firstly explores changes to the sector since 2010 both in terms of its economy and also narratives advanced to steer policy. Secondly the paper reconsiders key planks of the Coalition Government's policy agenda, notably for public service delivery, funding, localism and scrutiny. Thirdly, we consider the political dimensions of the policy debate. In conclusion we set out a series of issues which face the voluntary and community sector, its relationship with the state, and wider challenges of democratic legitimacy and renewal. We argue that these themes should not be seen in isolation, but as a series of interacting agendas advanced by actors and institutions through a network of alliances.
\end{abstract}

Keywords: voluntary and community sector; Coalition Government; public service delivery; austerity; civil society.

\section{Introduction}

This paper reviews changes to the policy environment for the voluntary and community sector since the formation of Coalition Government in the United Kingdom in May 2010. We return to a paper we published in the lead up to the General Election (Crowe, Dayson and Wells, 2010) which asked whether the General Election would represent a disjuncture or continuation in voluntary and community sector policy making, concluding that it would represent a disjuncture: 'the primary concern for many voluntary and community sector organisations will be navigating the new policy terrain to sustain and develop their activities' (Crowe, Dayson and Wells, 2010: 32).

In 2011, People, Place and Policy (PPP) published a special issue on the policy idea of Big Society. The editorial to this issue drew out extracts from the Coalition Government on 'social action' (HM Government, 2010). 


\section{Social Action: Extracts from the Coalition Agreement}

We will take action to support and encourage social responsibility, volunteering and philanthropy, and make it easier for people to come together in their communities and help one another.

We will support the creation and expansion of mutuals, co-operatives, charities and social enterprises.

We will give public sector workers a new right to form employee-owned co-operatives and bid to take these over the services they deliver.

We will train a new generation of community organisers and support the creation of neighbourhood groups across the UK, especially in the most deprived areas.

We will take a range of measures to encourage charitable giving and philanthropy.

We will introduce the National Citizen Service.

We will use funds from dormant bank accounts to establish a 'Big Society Bank', which will provide new finance for: neighbourhood groups, charities, social enterprises and other non-governmental bodies.

We will take a range of measures to encourage volunteering and involvement in social action.

This previous PPP special issue sought to do two things. Firstly, it drew on evidence to challenge and critique different components of the Big Society, notably around giving, civil participation and differences between places. Secondly, it suggested a more fatalistic reading of the Big Society in that it advanced an analysis and template for the UK in a post-welfare state, more contingent and changing world. It saw Big Society as an agenda which recognised the declining economic and political power of the UK in a changing and more fluid world. As such it was argued that the Big Society was not about the exit of the state from welfare, but that the responsibility for the provision of welfare should rest much more with individuals and society. Ultimately, though we argued that agendas such as the Big Society cannot be divorced from (party) political strategy.

This paper returns to many of these themes. It firstly explores changes to the sector since 2010 both in terms of its economy and also narratives advanced to steer policy. Secondly the paper reconsiders key planks of the Coalition Government's policy agenda, notably for public service delivery, funding, localism and scrutiny. Thirdly, we consider the political dimensions of the policy debate. In conclusion we set out a series of issues which face the voluntary and community sector, its relationship with the state, and wider challenges of democratic legitimacy and renewal.

Much of the narrative concerning the sector since 2010 has focused on various effects of austerity: the implications for the poorest groups and areas in the UK which the sector works with; the direct impact on the sector's income; and the reshaping of income in a far more competitive environment. The following quotes from two key sector leaders bear this out.

\section{Austerity: how has the sector changed since 2010}

'[C]harities have had to spend every last penny just to keep their heads above water. The charity sector has already taken a significant hit and we must act quickly to ensure that communities are not deprived of vital services.' 
(Sir Stuart Etherington, chief executive of the National Council for Voluntary Organisations, speaking on 5 March 2012)

'The cuts that are being imposed on local government and the health service are taking place now. So there are a lot of very worthwhile programmes - for example volunteers working in child protection as promoted by the minister for children which are now under threat of closure.'

(Dame Elisabeth Hoodless, chief executive of Community Service Volunteers, speaking on 7 February 2011)

However, it must also be acknowledged that our understanding of the sector is incomplete, with the full effects of austerity unlikely to become clear for many years, if at all.

The Emergency Budget in June 2010 and subsequent Spending Review signalled the Coalition Government's intent to cut the UK budget deficit quickly. Spending cuts have not been even, international development and health were 'protected' whilst all other Departments faced significant cuts. Most significant by the proportion of cuts was the Department for Communities and Local Government (over 60 per cent from 201011 to 2014-15) but in terms of scale the cuts to the DWP and welfare budgets were the largest. A further consideration has been the speed of cuts: quickly undertaken in Communities and Local Government but slower in Departments such as Justice. For further information, Gemma Tetlow of the Institute for Fiscal Studies provides an excellent summary of these changes and the implications of the 2013 Spending Review for expenditure (Tetlow, 2013). Further to this austerity has an uneven geographic effect. This is shown most starkly in work by Beatty and Fothergill, Hitting the Poorest Places Hardest (Beatty and Fothergill, 2013).

A picture of how the sector has fared during this period requires both a national and local perspective. Nationally, the NCVO's Almanac Series has charted changes in the sector's income and expenditure since the 1990s. The most recent edition (2013 http://data.ncvo-vol.org.uk/category/almanac/), draws on data for 2010/11 to provide a picture of the sector at the start of the Coalition Government. It shows that while the UK economy struggled, the voluntary sector's income grew, increasing by nearly $£ 2$ billion to $£ 38.3$ billion. However, NCVO's analysis indicates that increases in inflation have eroded the value of this income and real terms income is lower than in 2006/07 and that 2007/08 represented "peak funding" for the sector. The sector's spending also fell in real terms in $2010 / 11$ by $£ 800$ million. This followed increases in spending in the recessionary years of 2008/09 and 2009/10, leading NCVO to suggest that any spare capacity had already been used to meet extra need in hard times.

Research undertaken by David Clifford and colleagues at the Third Sector Research Centre has shown that the distribution of charities across the United Kingdom is uneven, leading to speculation that there may exist charity deserts, and that the impact of public funding cuts across the sector will be uneven, both in terms of place and service area (Clifford et al., 2012). Clifford (2012) also identifies that such patterns may be even more stark at a neighbourhood level, speculating that state resources are necessary in deprived places to address these deficits. Such deficits are exacerbated by the approach to public sector spending cuts taken by the Coalition government.

Area level data on the sector paints a very similar picture. Research undertaken in Greater Manchester (Dayson et al., 2013) identified year on year reductions in the sector's real terms income at a city region level between 2009/10 and 2011/12: it fell by two per cent between 2010/11 and 2011/12 and there was a larger reduction of five per cent between 2009/10 and 2010/11. Variations in income changes were 
identified by organisation size with medium sized organisations (annual $£ 100,000-£ 1$ million) most severely affected. Analysis of the financial reserve levels reported by organisations in Greater Manchester provided further insight into the financial health of the sector at an area level. The research found that 15 per cent of organisations had reserve levels of less than one month's expenditure, and a further 26 per cent had reserves that covered less than three months expenditure. Reserves are important as they provide organisations with funds to fall back on in the short term should other sources of funding reduce or be withdrawn. They also provide organisations with the flexibility to develop new and innovative activity that might not have attracted external funding from the outset. Organisations with low reserves relative to expenditure are therefore more likely to be restricted in their ability to adapt if key external funding is lost. The findings led the authors to suggest that up to two-fifths of all organisations in the sector could be vulnerable should their funds be severely reduced or withdrawn. They concluded that in reality it is likely to be the medium and large organisations in this category that are most at risk: they have greater financial commitments and require higher levels of income to carry out their work.

Data on how the sector has been affected by public sector cuts are less readily available. In NCVO's Almanac analysis for 2010/11 represented the calm before the storm. Income from government mirrored government spending, with an increase in cash terms of $£ 616$ million between 2009/10 and 2010/11. However, in their 2011 response to the Giving Green Paper NVCO estimated that if the voluntary and community sector were to experience reductions in public sector funding equivalent to the 27 per cent planned cut in local government support, it would amount to $£ 3.3$ billion being lost from the sector each year. This represents around nine per cent of total sector income.

Austerity is therefore having myriad effects across the sector. These are being felt unevenly. Moreover, this is a dynamic process with many consequences unforeseen. Macmillan (2012) has captured this upheaval in his introduction of the term the Great Unsettlement - a term used to convey the turmoil in the sector and in particular the unsettling of the relationship between the state and sector. Macmillan and McClaren (2011) have also suggested that a response from the leaders of the voluntary and community sector is required and at the heart of this must be a strong narrative vision for the sector and more broadly civil society. Without such a narrative, which responds to the sector-wide transformations that are at play, the focus appears on important, but lower order considerations around value for money, collaboration and merger, and organisational survival.

\section{Policy Agendas}

Alongside austerity our earlier paper also identified four other inter-related areas which would shape the post-election terrain: public services delivery, models of (public) funding, localism and scrutiny of the sector. This section explores developments in each. Firstly, in terms of public services delivery the leitmotif of the Coalition Government has been that there should be no presumption that the public sector should be the default provider of public services. As a recent review of the Open Public Services White Paper states: 'When the Coalition first came to power, the state was still the default provider of most public services...there were clear signs that the old centralised model of public services delivery was unable to meet the complex needs of the 21st century' (HM Government 2013: 1). In some ways this is a rhetorical statement to position the Coalition as different to previous Governments, and in particular New Labour, to highlight real or perceived failings of the state, and to suggest that the needs of the $21^{\text {st }}$ century are complex and require new solutions. As such the Coalition 
government has sought to challenge existing models of delivery in many areas. Reforms have stretched from the promotion of 'individualised services' (such as personal health budgets), neighbourhood services (notably the Community Right to Challenge and Community Organisers initiatives), commissioned services (especially the extension of payment by results models to create markets for service delivery and outcome achievement), and more broadly the notion that there would be a diversity of provision.

What has been telling in these developments has been that whilst the sector is mentioned and occasionally celebrated for its work, there is little sense that it in some ways is a special or privileged partner of the state. Moreover, there has been limited discussion of the voluntary and community organisations as even a sector. In this regard individual organisations are becoming players in a market where there is a premium placed on efficient and effective delivery. The political tone of debate has changed markedly, cloaked in the need for change due to fiscal constraints and bringing greater attention to users and customers of services. The voluntary and community sector's criticism of the Work Programme and the squeezing out of sector led provision in the prime/sub-contractor model of delivery, supports this position most clearly. These concerns are set out in the NCVO's report on the sector's experience of the Work Programme (NCVO, 2012), although as Dave Simmonds and others have noted these problems may not be solely confined to the voluntary and community sector (Simmonds, 2012).

These developments play out across an existing institutional landscape, with considerable variation across policy domains and between localities. The common narrative of the 'great unsettlement' is thus one of a multitude of competing and separate smaller narratives of change in the sector.

Secondly, the Coalition has continued New Labour's interest in bringing new forms of capital to the voluntary and community sector. However, this interest has not solely been with loan funding but most notably through the piloting of Social Impact Bonds as a means for any delivery organisation to raise commercial and quasi commercial funding. The basis for SIBs has been that a return to the investor can be offered where a specified and clearly measurable threshold of outcome achievement has been passed. The most high profile SIB to date has been the Peterborough Prison Pilot led by St Giles Trust. The outcome measure here is offender recidivism, at face value a straight-forward and measurable objective, but in reality more complex and imbued with risks of 'gaming'. In this context 'gaming' can be seen as the establishment of a payment-reward system which may encourage delivery organisations to target support on those closest to the labour market. The interest for the state and markets is that the returns can be funded on the back of 'cashable savings' received by the state. Other SIBs are in advanced stages of development and appear to offer opportunities where there are clear links between outcomes, cashable savings and the part of the state (for instance local authorities or Ministry of Justice) where the cost saving is achieved.

The Coalition commitment to launch Big Society Capital (BSC), a wholesale bank for the voluntary and community sector was achieved on the 4 April 2012, and is the vanguard initiative to deliver the Cabinet Office's ambition to grow the social investment market. BSC was initially funded by the use of monies in dormant bank accounts but in time it is seen as a vehicle to attract and disperse funding from a range of state and market sources. The Prime Minister has personally promoted the social investment market as a new and innovative approach for funding social action. The most high profile development has been the hosting at the time of the G8 Summit in June, an international social investment summit. Although not receiving widespread media coverage, these developments perhaps indicate the directions government wishes to pursue in funding social policy in the future. 
Nonetheless, social investment is a relatively new policy and academic concept (Nicholls, 2010; Wells, 2012). It is used with some fluidity with respect to both the recasting of the welfare state and models of funding which explicitly combine financial and social objectives. In the latter guise, social investment might include a stance by investors to place money in businesses which demonstrate greater corporate social responsibility or the provision of finance for activities which bring social benefits. It therefore brings together the language of investment and financial markets, and in particular terms such as risk and returns, with that of social policy. The UK government's green paper Growing the Social Investment Market: A vision and strategy (HM Government, 2011) is a good example of a trend which started under New Labour in seeking new forms of finance for the voluntary and community sector. A report published in September 2012, The First Billion (Brown and Swarsky, 2012) and commissioned by Big Society Capital, the Coalition Government's key intervention in this field, suggests that the social investment market in the UK could grow from $£ 165$ million (2011) to $£ 1$ billion (2016). This optimism is not limited to the UK and is seen in some quarters as a global trend (O'Donohoe et al., 2010). These developments are not confined to the state or the market. A series of papers for the NCVO Funding Commission also provides evidence of this trend in parts of the voluntary and community sector (see for example Ludlow, 2009).

Thirdly, at the heart of the Coalition agreement were agendas to promote, separately and jointly, localism and community action. The early part of the Coalition Government focused on putting into practice the Big Society agenda. This included specific flagship initiatives such as the National Citizen Service but also through changes to the planning system, giving communities a range of rights to either block or promote certain development.

However, the Big Society as a political idea capable of galvanising disparate policies together and which can be communicated effectively to the electorate appears to have largely failed and is rarely mentioned now in political and policy making circles. Whilst individual initiatives such as NCS, the Community Right to Control or Community Budget Pilots have been rolled out, they do so very much under the language of public service reform and not the Big Society. Localism and community action agendas have very much been cast in terms of austerity and form part of the great unsettlement. What are most interesting in this arena have been the new alliances and initiatives which have been formed locally in response to austerity. On the one hand, the local statutory sector is cutting funding to organisations, but on the other, many local statutory bodies are having to work with the voluntary and community sector to find ways to secure, at the very least, adequate wellbeing for all local residents. However, as research on the geographical implications of welfare reform show (Beatty and Fothergill, 2013), local communities in the former industrial parts of the United Kingdom are facing both disproportionate cuts to public sector finance but also disproportionate cuts to funds entering local areas as welfare payments. This is further compounded by the limited return to national economic growth being confined to the southern parts of the United Kingdom.

Finally, in 2010 we suggested that there would be far more attention to issues of scrutiny in its broadest sense including regulation and value for money in service delivery. Again, these debates reflect a far more competitive operating environment for the voluntary and community sector since 2010. A notable development has been the passing of the Social Value Private Members' Bill. The Public Services (Social Value) Act 2012 became law on the 8th March 2012. From 31st January 2013 the Act came into force and commissioners and procurers must adhere to it. The Act requires a procuring body, such as a local authority, to take into account the social, environmental and economic wellbeing of an area in procurement decisions and to consider how such 
wellbeing might be improved. In theory the Act provides a basis for procurement which is not driven primarily by cost but by considerations of wider benefits. An implication for the sector beyond ensuring that procurement bodies implement the act in name and spirit, is to better demonstrate the outcomes they achieve. This however raises a concern that the Act may not be implemented as intended, with statutory bodies taking a tokenistic approach. Moreover, it is too soon to make a full assessment and for the moment such developments must be considered with some element of caution in terms of their implications for the sector.

More broadly, the demonstration of outcomes, impact or value to funders, users and trustees of voluntary and community sector organisations has risen in importance. In part this is a response to austerity and a requirement of funders. However, it is also part of a wider agenda which is changing the governance and scrutiny of the voluntary and community sector and in particular charities. This is shown by revisions to the 2011 Charities Act and the clarification of the public benefit test for charities. At the same time a reorganised Charities Commission has sought to move from a regulatory stance based on prevention and policing the sector, through its reporting requirements, to one based on prevention. Furthermore, the sector is increasingly open to scrutiny by the media, whether this be in terms of the salaries of chief executives or the prevalence of zero hour contracts (Ainsworth, 2013). Overall, these separate aspects of scrutiny, governance and impact demonstration suggest a significant change in the operating environment for the voluntary and community sector.

\section{Conclusion: where next for the voluntary and community sector?}

As we and others have argued there is considerable uncertainty around the future for significant parts of the voluntary and community sector. With such change it is difficult to foresee where, if at all, there will be a return to some form of settled state. The sector is responding both to a crisis in funding but more broadly a foundational crisis around its very role and purpose. It is a political debate in so far as locally and nationally organisations and 'key players' of the sector seek position, strategic alliances and resources. Relations between the state, the voluntary and community sector and the market are thus in something of a state of flux. The emergence and growth of social investment is a good example of this. What also appears to characterise change since 2010 is the variety of responses. Such variety is between localities, sectors and organisations. Indeed local parts of national organisations may collaborate actively in one place yet compete in another.

Our focus has largely been with the relationship between the sector, such that there is a coherently definable sector, and the state. This relationship we would argue needs to be much broader and consider relationships with the market. Such relations come in different forms, from the introduction of market based discourses and approaches into voluntary and community sector decision making through to attempts to wire-in private sector capital to activities for social benefit. A future agenda for researchers we argue should be at the intersection of each sector's institutions, actors and discourses.

The voluntary and community sector, and more broadly civil society, cannot be seen as static. The response of groups of people, within an organisation or as part of a looser network, in challenging established positions and campaigning against injustice has always been crucial to the renewal of the voluntary and community sector. The emergence of Occupy as an international movement to challenge corporate and political power is the most prominent example. However, other examples include local and national mobilisation of new groups against austerity and cuts. Most recently the campaigning role of the sector has challenged the Lobbying Bill which if enacted could 
severely curtail the political campaigning and influencing role of charities. Understanding change in the voluntary and community sector and civil society should consider the role of the state, but also more fluid networks of actors and the use of new means of mobilisation, most notably the use of social media.

An arena not considered here but which will come to the fore is the relationship between civil society and party politics. Political parties have traditionally been an important focal point for civil engagement. However, membership of the three main political parties in England has been in sharp decline since 2010. Alongside declining turnout in local, national and European Parliament elections, general disquiet and protest in the face of austerity, it has been part of an emerging crisis in traditional forms of parliamentary democracy. Such debates and the relationships between representative and participative democracy are of course not new and there are of course lessons from previous experiments to consider, whether nationally or in the sphere of community action. An arena for debate in the lead up to the next General Election and beyond will therefore be around the relationship between party politics and civil society. The role of the voluntary and community sector as a mediator in this debate will be crucial and distinguishes the sector from both the state and the market. For the moment, though, there is an absence of discussion around these issues and indeed what each party's manifesto may contain at the time of the next General Election.

Finally, the Crowe et al (2010) article identified five key areas which would shape policy and debate around the voluntary and community sector: around austerity, public service delivery, funding, localism and scrutiny. These issues have all been part of the voluntary and community sector landscape for the last three years. However, what really matters is which ones are most important, how these agendas interact, and what politics are at play in terms of actors, institutions and alliances. This article hopefully has begun to fill in some of these gaps and suggest how the voluntary and community sector landscape will develop in the run up to the next General Election and beyond.

*Correspondence Address: Peter Wells, CRESR, Unit 10, Science Park, Howard Street, Sheffield, S1 1WB. Email: p.wells@shu.ac.uk.

\section{References}

Ainsworth, D. (2013) And what about the newspaper fat cats? Blog on Third Sector (13 August 2013). Blog accessed on the internet on 27 September 2013. Available at: http://thirdsector.thirdsector.co.uk/

Beatty, C. and Fothergill, S. (2013) Hitting the Poorest Places Hardest: the local and regional impact of welfare reform. Accessed 23 September 2013: www.shu.ac.uk/research/cresr/sites/shu.ac.uk/files/hitting-poorest-placeshardest 0.pdf

Brown, A. and Swersky, A. (2012) The First Billion: A forecast of social investment demand. London: Big Society Capital. Accessed 13 December 2012: www.socialfinance.org.uk/sites/default/files/thefirstbillion.pdf

Clifford, D. (2012) Voluntary sector organisations working at the neighbourhood level in England: patterns by local area deprivation. Environment and Planning A, 44, 5, 1148-1164.

Clifford, D., Geyne-Rahme, F. and Mohan, J. (2012) Variations between organisations and localities in government funding of third-sector activity: evidence from the national survey of third-sector organisations in England. Urban Studies, 1-18. 
Crowe, M., Dayson, C. and Wells, P. (2010) Prospects for the Third Sector. People, Place and Policy, 4, 1, 29-32.

Dayson, C., Eadson, W., Sanderson, E. and Wilson, I. (2013) Greater Manchester State of the Voluntary Sector 2013. Manchester: GMCVO. Accessesed 23 September 2013: http://www.gmcvo.org.uk/sites/gmcvo.org.uk/files/Greater\%20Manch ester\%20State\%20of\%20the\%20Voluntary\%20Sector\%202013\%20FULL_0.pdf

HM Government (2010) The Coalition: our prgramme for government. London: Cabinet Office. Accessed 23 September 2013: https://www.gov.uk/government/uploads/ system/uploads/attachment data/file/78977/coalition programme for govern ment.pdf

HM Government (2013) Open Public Services (Annual Implementation Update Report). London: Cabinet Office. Accessed 23 September 2013: www.openpublicservices.cabinetoffice.gov.uk/

HM Government (2011) Growing the Social Investment Market: A vision and strategy. London: HM Government.

Ludlow, J. (2009) Capitalising the Voluntary and Community Sector: a review. Paper submitted to the NCVO Funding Commission. Accessed 23 September 2013: www.ncvo-vol.org.uk/sites/default/files/Capitalising the voluntary and comm unity_sector_0.pdf

Macmillan, R. (2012) The great unsettlement - let's talk about it. TSRC Blog. Accessed 23 September 2013: http://www.tsrc.ac.uk/Blog/tabid/504/Entryld/29/Thegreat-unsettlement-let-s-talk-about-it.aspx

Macmillan, R. and McClaren, V. (2011) Inspiring Local Leadership. A Report of NAVCA's leadership Roundtable. Sheffield: NAVCA. Accessed 23 September 2013: http://assets.navcadevelopmentserver.co.uk/existing/NR/rdonlyres/cdff73215d1f-41f1-93e9-060fbb05ff1b/0/inspiringlocalleadership.pdf

NCVO (2012) The Work Programme: Perceptions and Experience of the Work Programme. London: NCVO. Accessed 23 September 2013: www.ncvovol.org.uk/sites/default/files/sig survey june 2012 report 17.9.12.pdf

O'Donohoe, N., Rozeira De Mariz, F., Reille, X., Kneiding, C. and Rozas, D. (2010) All Eyes on Microfinance Asset Quality: Microfinance Global Valuation Survey 2010. New York: JP Morgan Global Research.

Simmonds, D. (2012) The Work Programme and the Voluntary Sector. CESI Blog. Accessed 23 September 2013: www.cesi.org.uk/blog/2012/oct/workprogramme-and-voluntary-sector

Tetlow, G. (2013) "We shall squeeze ... until the pips squeak". Institute for Fiscal Studies Post-Spending Review Round Up. Presentation Slides (27 June 2013). Presentation accessed on the internet on 27 September 2013. Available at: http://www.ifs.org.uk/budgets/sr2013/gemma_tetlow.pdf) 